\title{
EXPERTISE AND GLOBAL WATER GOVERNANCE: HOW TO START THINKING ABOUT POWER OVER WATER RESOURCES?*
}

\begin{abstract}
Rene URUENA**
RESUMEN: El poder sobre los recursos del agua ha sido ampliamente difundido. Partiendo de este punto, este trabajo explora los antecedentes sobre la política del manejo del agua y argumenta la existencia de un espacio regulatorio llamado "Gobierno Global del Agua" (GGA). El cual es un área de especialidad en el que la política es negativamente percibida y expresamente rechazada. A través de este movimiento, la especialidad se vuelve esencial para entender el control de recursos del agua. La postura del autor es que la especialidad no es una atribución sino una relación de poder. Como tal, es normalmente percibido como antidemocrático, por lo tanto, la denuncia hacia la regla de especialidad es normalmente seguida por las llamadas reglas mayoritarias y aún así las características específicas de esta especialidad no entran dentro de esta denominación. Por esta razón son necesarios medios alternativos de resistencia, un grupo de expertos podrían ser la solución.
\end{abstract}

ABSTRACT: Power over water resources has been mostly spared of critical scrutiny. Departing from such trend, this paper explores the background of water politics, and argues the existence a regulatory space called "global water governance" (GWG). GWG is an "area of expertise", wherein "politics" is negatively perceived and expressly rejected. Through this move, "expertise" becomes the corner stone to understand governance of water resources. I submit that expertise is not an attribution, but a power relation. As such, it is commonly perceived as undemocratic; hence, the denunciation of "expert rule" is usually followed up by a call for some sort of majoritarian rule. And yet, the specific characteristics of expert power turn futile such call. For this reason, alternative vehicles of resistance are needed; and accountability of experts may be the place to look.

RÉSUMÉ: Le pouvoir sur les ressources de l'eau a été vraiment délayé. En débutent par cet ide, cet travail fait un exploration des antécédents sur la politique du manage de l'eau et fait un argumentation de l'existence de un espace régulateur appelle "Gouvernance Global de l'eau" (GGE). GGE et un area de spécialité dans la quel la politique est négativement aperçu et expressément refuse. Au travers de ce mouvement "l'spécialité" est élémentaire pour comprendre la gouvernance des ressources de l'eau. J'ai l'opinion que la spécialité c'est ne pas un attribution mais un relation de pouvoir. Comme ça, est normalement aperçu comment anti démocratique, pour tant, la dénonce a la règle $d$ 'spécialité est normalement suivi pour les appelaient règles mayoraux, et même comme ça les caractéristiques spécifiques de cet spécialité n'entrait pas dans cet dénomination. Pour cet raison c'est sont nécessaires des solutions alternatives de résistance, un group d'experts pourrait être la solution.

* Artículo recibido el 30 de abril de 2008 y aceptado para su publicación el 26 de agosto de 2008 .

** Research Fellow, Centre of Excellence in Global Governance Research. E-mail: rene.uruena@helsinki.fi. 
SUMMARY: I. Introduction. II. From international water law to global water governance. III. It takes two to tango. Expertise as a form of power. IV. Assessing GWG: expertise and the limits of the call for majoritarian rule.

\section{INTRODUCTION}

The future is drying out. By 2025 , up to $40 \%$ of the world's population could be living in water scarce regions ${ }^{1}$ and yet, governance of water resources seems to be mostly spared of critical scrutiny.

Indeed, whenever we think of the "water problem", weight is shifted between the "context" and the "foreground" of water regulation: issues are featured either as inevitable realities of nature or society (like water scarcity) or as policy choices, taken freely by sovereigns within the limits of given restraints (for example, privatization of water supply).

There is, however, a different set of question to be asked. It is possible to go beyond the "foreground" and its apparently free choice among policies, and yet avoid subscribing to the fateful determinism of the natural "context". ${ }^{2}$ It is possible, in other words, to focus in the background norms and institutions of water politics. ${ }^{3}$

The "background" marks a space between foreground politics and their given context. On one hand, the "foreground" is composed by the decisions of those who openly exercise power, like presidents or ministers. "Context", in turn, is defined by inevitable circumstances where we see no one taking any evident decisions. And then, in the middle, we have the "background": a space discernible by the perception that "other

1 Source: UNEP \& Stockholm International Water Institute [SIWI], Challenges of Water Scarcity (SIWI, 2005) at 8.

2 Yet, the notion of context's inevitability is controversial in itself. Issues such us water scarcity can certainly be read as force majeure, but also as an effect of bad policy choices (global warming gives an example of how that move is performed). They would, then, stop being given, and thus stop being "context". At any rate, the possibility of moving "context" to the foreground only underscores the importance of a middle ground, as we now turn to see.

3 The notions of "foreground", "background" and "context" were first proposed in: D. Kennedy, "Challenging the Expert Rule: The Politics of Global Governance", 27 Sydney Law Review, 2005, 5-12. 
people than those who seem to be in charge are making the real decisions". ${ }^{4}$

These other people are, in most accounts, the "experts". Background politics is expertise's natural habitat. ${ }^{5}$ It is there that experts deploy their power and influence, and are perceived to do so in a manner that lacks transparency, legitimacy and accountability. Shortly said: if democracy is the name of the game, then expert rule seems to be performing quite poorly indeed. ${ }^{6}$

Water politics is by no means an exception. This paper explores the background of water politics, by arguing the existence a regulatory space called "global water governance" (GWG), which is fundamentally dependant on experts and the notion of expertise.

This dependence, though, has unexpected effects. If faced with a problem of undemocratic expert rule, one would immediately call for more democracy. However, as will be argued here, the mere outcry for majoritarian rule in GWG is missing the point. It is calling the wrong bluff, and letting the real one go unchecked.

Indeed, this paper proposes that the specific characteristics of expert power turn futile the call for majoritarian rule. This is true for GWG, and may be true for other expert dependant systems. We may need to find alternative vehicles of resistance; and, as is argued towards the end, accountability of experts may be a place to start looking.

There are three parts of my argument. The first one is of descriptive nature and draws an outline of the way governance of water resources works. In it, the notion of "global water governance" (GWG) is introduced, and the role of expertise as the crucial trait of GWG is explored.

4 Ibidem at 12.

5 Cfr. D. Kennedy, op. cit., note 3, at 14.

6 To be sure, democracy may not be the game at all. Expert rule would get far better grades if read as a problemsolving devise, or as a way of advancing rationality in public administration. Such alternative criteria are mostly re-enactments of the standard argument on independent regulatory agencies which states: "true, this is not democratic, but it is not supposed to be democratic anyhow". Admittedly then, taking the democratic approach to read expert rule does imply a normative judgment, which is justifiable in many senses; see, for example: D. Held, Democracy and the Global Order, Polity Press, 1995; also: H. Patomäki \& T. Teivanen, A Possible World: Democratic Transformations of Global Institution, Zed Books, 2004. The seminal text in defense of regulatory agencies is: G. Majone, "Regulatory Legitimacy", in: G. Majone, Regulating Europe, Routledge, 1996, at 284 . 
The second part approaches the problem of expertise as a form of power. Such section provides the elements necessary to assess the reality described in section one, and serves as the hinge whereon the whole discussion turns.

Finally, the third part proposes a normative assessment of GWG. It argues that, although GWG does shield water governance from majoritarian rule, calling for more majoritarian rule is not the answer; as such call is ineffective and perhaps counterproductive. This section then considers possible alternatives, and asks certain questions that seem relevant to start thinking about power over water resources today.

\section{FROM INTERNATIONAL WATER LAW TO GLOBAL WATER GOVERNANCE}

Governance of urban water supply has become a global concern in relatively recent times. Until the 1980 's, water was perceived to be an essentially domestic matter, which only exceptionally required international regulation. ${ }^{7}$ The key word was sovereignty. Water resources (and natural resources, in general) were deemed to belong to states as a matter of sovereignty. Use of water (or its "governance") was an attribution of the sovereign, which could only be limited by the rights of other sovereigns. ${ }^{8}$

Such approach provided the framework for intensive international regulation of water resources for more than a century. One of the earlier forms of international organization was the so-called "river commissions", starting with the Rhine example of $1815 .{ }^{9}$ There is also evidence of well established international customary water law ${ }^{10}$ and, on a similar vein, the International Law Commission worked for 27 years to develop

7 Cfr. M. Langford, "The UN Concept of the Right to Water: New Paradigm For Old Problems?" 21 Int. J. of Water Resources Development, 2005, 273.

8 For the changing role of sovereignty in the international law of natural resources, cfr. T. Kuokkanen, International Law and the Environment: Variations on a Theme, Kluwer, 2002, at 6. For a similar argument in the context of international water law, $c f r$. R. Urueña, "Recurso hídrico y la estructuración de derechos de propiedad bajo derecho internacional", 2 Regulación, 2006, 42.

9 Cfr. J. Klabbers, An Introduction to International Institutional Law, CUP, 2002, at 17 .

10 Cfr. J.W Dellapenna, "The Customary International Law of Transboundary Fresh Waters", 1 International J. of Global Environmental Issues, 2001, 264. 
and codify rules regarding non-navigational uses of international watercourses. ${ }^{11}$

This regulation drew a line on the sand, called it sovereignty, and vowed never to cross it. It came as no surprise, then, that the "black box" vision of the sovereign state was transposed to water resources, placing off-limits all water governance undertaken by organs within states. ${ }^{12}$ Sovereigns would interact with each other and perhaps clash but, as part (A) of Figure 1 below shows, their inner structure would remain unaffected.

Such rhetoric was appropriated by newly de-colonized states in the 1960 's, through the doctrine of permanent sovereignty over natural resources (PSRN). ${ }^{13}$ Given the pivotal rule played by natural resources in the colonial undertaking, PSRN became an important mechanism for ex-colonies to regain control and underscore their independence. ${ }^{14}$ The third-world, then, started to use the buzz word of the moment. But by then, the word had lost its hype. ${ }^{15}$ Sovereignty was no longer the key word in water governance. Although the base on which international water law had been structured was as clear as always, in the early 1990's, it began to lose importance. Though it was there, no one was looking at it anymore. All eyes were elsewhere. ${ }^{16}$

11 In 1963, UN-Secretariat presented a report on "Legal Problems relating to the Utilization and Use of International Rivers", which paved the road for Resolution 2669 of December 8 1970, commissioning the ILC with the study of the subject. After 27 years of drafts articles and negotiations, the Convention on the Law of the Non-navigational Uses of International Watercourses was finally adopted by the GA on 21st May 1997, through Res. A/51/229.

12 On the "black box" approach and its caveats, cfr. W. Ferdinandusse, "Out of the Black Box? The International Obligations of State Organs"; 29 Brooklyn J. of International Law, 2003, 46.

13 G. A Res. 1803/1962, 17 GAOR, Supp. 17, UN Docs. A/5217.

14 Cfr. A. Anghie, Imperialism, Sovereignty and the Making of International Law, CUP, 2005, at 211.

15 Anghie seems to suggest that, perhaps, it did so precisely because the third world began to use it. Cfr. Ibidem, at 235.

16 And yet sovereignty over water resources is very much there. If needed, decisive arguments of sovereignty can be competently be made today; $c f r$. e.g, J. Isaac, "The Essentials of Sustainable Water Resource Management in Israel and Palestine", 22 Arab Studies Quarterly, 2000, 13. 
Figure 1

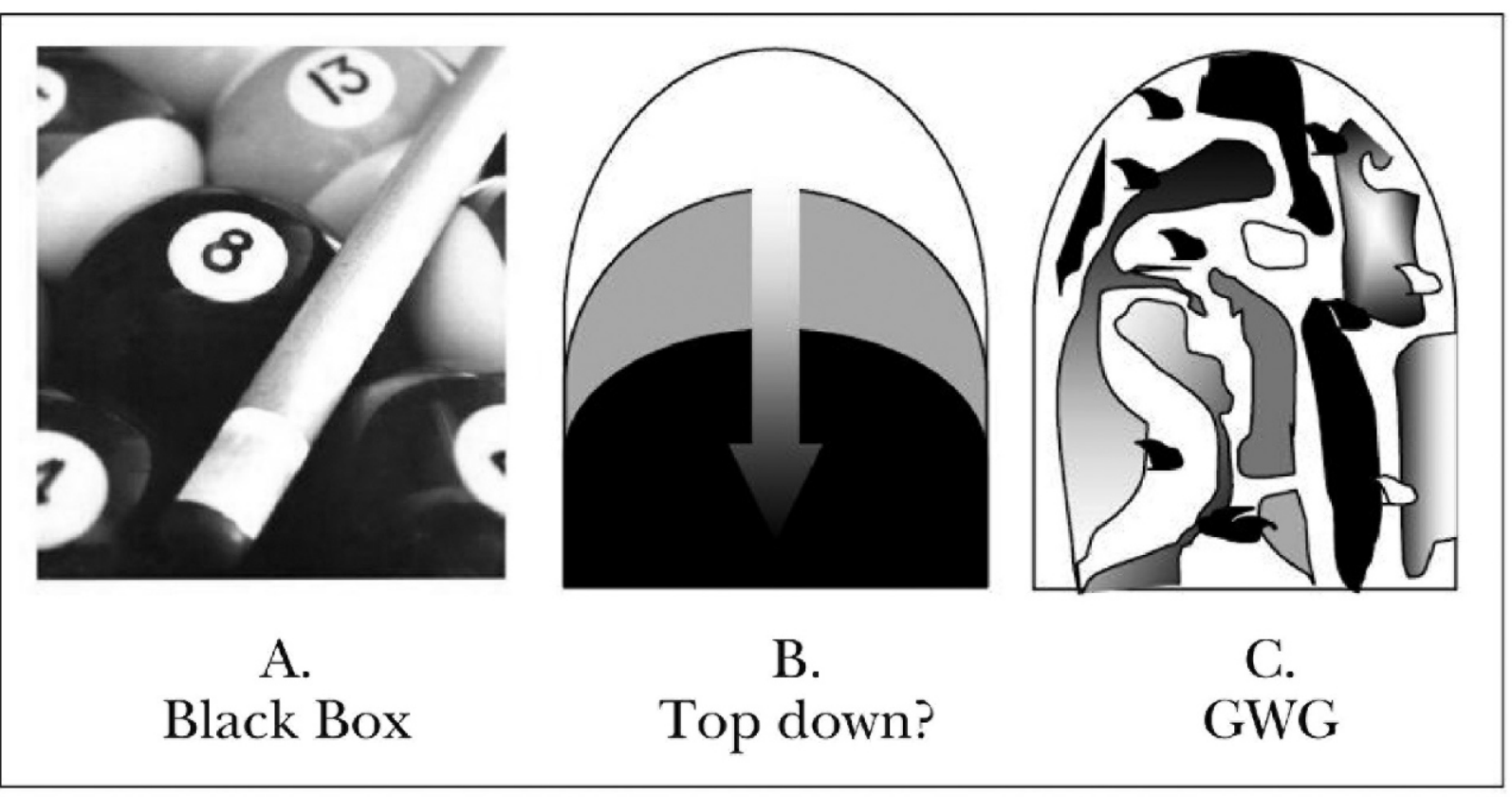




\section{The notion of global water governance $(G W G)$}

The last decade of last century marked a swift change in water governance. A new set of norms and regulatory machinery was put together. These norms and agencies were concerned with water issues, but also crucially oblivious of the domestic/international divide. And, once this move had been performed, global water governance (GWG) became possible.

GWG is a not regulatory undertaking itself, but a space: a space where regulation occurs. In GWG, water regulation is produced and enforced by national governments, international organization and regulatory networks. ${ }^{17}$ These actors, however, do not have a rigid hierarchical layout: depending on the issue, they reorganize and, not without conflict, impose over or yield to each other's field of action.

Indeed, water regulation is adopted not only by domestic governments, but also, as we shall see, within international organizations such as the World Bank (WB), the United Nations (UN) and even the World Trade Organization (WTO). And not only governmental organizations are of relevance: the all - private International Standards Organizations (ISO), for example, hosts two technical committees which develop crucial standards for water and related issues: ISO/TC 147 (Water quality), and ISO/TC 224 (Service activities relating to drinking water supply systems and wastewater systems - Quality criteria of the service and performance indicators). ${ }^{18}$

17 "Regulatory networks" is used here as "informal institutions linking actors across national boundaries and carrying on various aspects of global governance in new and informal ways", presenting also an intergovernmental element, defined by "pattern[s] of regular and purposive relations among like government units working across the borders that divide countries from one another and that demarcate the 'domestic' from the 'international' sphere" (A.M Slaughter and D. Zaring, "Networking Goes International: An Update", 2 Annual Review of Law and Social Sciences, 2006, 211 at 215).

18 ISO/TC 147 has 33 states and 20 governmental and non governmental international organizations as participants, plus 47 states as observers. ISO/TC 224 boasts 32 participant states, 8 organizations and 18 observers. ISO/TC 147 alone has developed 229 standards, and ISO/TC 224 is currently discussing three drafts of crucial importance for water supply: ISO/DIS 24510, 24511 and 24512 (cfr. www.iso.org/iso/standards_development.htm (last visit: 02.10.2007). On ISO and similarly private institutions of global relevance, $c f r$. J. Klabbers, "Reflections on Soft International Law in a Privatized World”, 104 Lakimies, 2006, 387. 
In this sense, GWG is not a top-down structure, as depicted in part (B) of figure 1. International regulation does not simply replace domestic law or is not imposed on it. On the contrary, domestic regulation is a critical component of GWG. By abandoning the focus on sovereignty, domestic regulatory agencies became as important as their international counterparts for understanding GWG.

This is not to say that domestic agencies are autonomous in any significant sense, but rather that their constraints are not simply imposed on "poor countries" by "those Washington pundits". Therefore, agency transplant, extraterritoriality of domestic regulation, model laws and the so called "harmonization" of domestic systems are all fundamental elements of GWG. ${ }^{19}$

Thus, for instance, so-called independent regulatory agencies of water resources spread through out the world (both in developed and developing countries) during the 1980 's..$^{20}$ This specific institutional arrangement created a distinctive sort of economic regulation that reflects, in turn, contradictory processes of norm creation: on one hand, a distinctively top-down process, via the imposition of regulation by international organizations on developing countries. But also other kind of processes, such as horizontal influence, through the transplant of specific answers from one regulatory context to the other; ${ }^{21}$ and even a bottom-up relation, through the influence of specific regulatory bodies on international organizations. $^{22}$

19 A good example of work in that direction is: V. Foster, Ten years of Water Service Reform in Latin America: Toward and Anglo - French Model, World Bank [WB], Water Supply and Sanitation Sector Board Discussion Paper Series., no. 3, 2005.

20 Cfr. F. Gilardi, "The Institutional Foundations of Regulatory Capitalism: The Diffusion of Independent Regulatory Agencies in Western Europe", Annals of the American Academy of Political and Social Science 598, 2005, 84.

21 For example, South Africa's regulatory framework of prepaid water meters was transplanted to several Latin-American countries during the early 2000's. Such south-south transplant may have negatively affected, even further, the population in need. Cfr. H. Deedat, "Viva Prepaids, Viva': Technology, cost recovery and access to water in the rural Northern Cape"; in: D. A McDonald \& J. Pape (eds.), The Crisis Of Service Delivery In South Africa, Zed Press and HSRC Publishers, 2002, 140. For an English language account of the effects of such transplant in Latin-America, cfr. J. Forero, "Who Will Bring Water to the Bolivian Poor?", NYT, December 15, 2005.

22 A case in point is England and Wale's Water Services Regulation Authority (OFWAT) whose work normally inspires World Bank's policy recommendations to de- 
Similarly, regulation within GWG impacts both states and private parties alike: GWG's effects are not organized along the line of public international law's subjects, but as a function of the actor's interest as stakeholders.

Water regulation is intended to apply to private and public suppliers alike. And, more importantly, as we shall see below, it creates rights and duties for states and also for private individuals and companies within such states.

GWG is, then, a frame wherein worldwide power over water resources is exercised. An exercise that is far from being coherent or structured, as is shown in part (C) of Figure 1.

In this sense, GWG is closely related to what Kingsbury, Krisch and Stewart have called the "global administrative space":23 "a space, distinct from the space of interstate relations governed by international law and the domestic regulatory space governed by domestic administrative law, although encompassing elements of each".

However, GWG seems to have one feature that further complements the preceding definition. Up to now, GWG's as an administrative space has been defined by its internal features: how it overlooks the domestic/international divide, how its hierarchies are fluid, and how it is legally informal. And yet, as a space, GWG cannot be all - including; it requires definition of its external boundaries. Such is question that is marks the essential misunderstanding of how governance of water resources works: what makes the inside/outside of GWG?

veloping countries. A clear example, among many, is OFWAT's cost accounting guidelines for water activity analysis, which was later adopted as "full cost accounting" (FCA) by the World Bank's initiative to "get the finances right", by the EU's Water Framework Directive and, eventually, by domestic administrations from Ontario (Canada) to Sierra Leone. Cfr. S. Renzetti, Full Cost Accounting for Water Supply and Sewage Treatment: A Case Study of the Niagara Region, Canada, World Bank, 2003. This is not just some technical gaiety: unlike other methods of accounting that record only current outlays of cash, FCA takes into account all of the monetary cost of resources used for water services, which may differ from cash outlays. These costs have to be recovered in the price paid by the final water consumer. Therefore, in practice, FCA implies that more costs have to be recovered, thus making the price of water services higher.

23 B. Kingsbury, N. Krisch \& R.Stewart, "The Emergence of Global Administrative Law", 68 Law and Contemporary Problems, 2005, 15 at 25. 
2. The outer boundary: Politics $v$. expertise as the defining trait of $G W G$

GWG is not a natural phenomenon. It does not "emerge" in same sense that an island emerges from the waters. It is a constructed reality, a rhetorically created space. As such, it is defined through rhetorical moves. In our case, the main rhetorical move is the advancement of a dichotomy (expertise/politics) which gives, in turn, ground to a normative assessment. Through this move, GWG is created.

Indeed, GWG's external borders are defined by a sharp division between expertise and politics: the first is featured as rational, efficient and fair; the second as the exact opposite.

Such dichotomy involves in turn a default normative assessment. The essential problem of water governance, the argument goes, is politics. If only we could make water governance a bit more technical, then most of the truly pressing issues regarding water would be solved. If only know-how could be exported, suggested; even imposed.

GWG is, thus, the effort of taking water issues away from politics, and into expertise. Appealing to international law is relevant, not because it is "international", but because it is featured as apolitical. Water governance leaves the domain of the nation-state not out of concerns of sovereignty or provision of "global public goods", 24 but because the nation-state is seen as the stronghold of politics. And we want to leave politics behind.

Being performed through language, this move is bound to be decentralized and indeterminate. There is (at least formally) no global centre of rhetoric pushing the experts/politics dichotomy. Rather, GWG is framed through the irregular cadence of rhetorical shifts, all of which seem to form a palimpsest that ultimately gives the feeling that the dichotomy has always been there.

Now, there are two ways to tackle this issue. The first one is to ask why this dichotomous rationale has grown to be the standard approach to water governance in the last decade. Such question, although evidently

24 Cfr. J. Stiglitz, The Theory of International Public Goods and the Architecture of International Organizations, UN Background Paper 7, Department for Economic and Social Information and Policy Analysis, 1995; also: I. Kaul, I. Grunmberg, \& M. Stern "Defining Global Public Goods", in: I. Kaul, I. Grunmberg, \& M. Stern (eds.), Global Public Goods-International Cooperation in the 21st. Century, OUP, 1999. 
relevant, exceeds the scope of the present paper and will not be dealt with here.

The second way is to ask how this dichotomous approach has taken over. Such question is instrumental to understand the role of expertise in GWG, and will prove useful to see why the unqualified demand of majority rule in water governance may, in fact, be an obstacle for creating change.

GWG is built through four different redefinitions of water supply as a global problem. Water supply is simultaneously reframed as a condition for development and as an environmental problem; as a business and as a human right problem. Through these four redefinitions, the dichotomy is naturalized, and GWG is created. ${ }^{25}$ Let us turn now to each of these redefinitions.

\section{A. Water supply is a condition for development}

The first wall of GWG's outer boundary is the redefinition of water supply as a condition for development. Through this move, water supply falls squarely within the mandate of international financial institutions, and becomes a global matter by definition. ${ }^{26}$

The World Bank (WB) played an important role in this move. Although it had been lending for water projects before, it was only until 1993, after the Rio Earth Summit, ${ }^{27}$ that the Board endorsed the Water

25 Naturalization refers the move whereby "existing social arrangements come to seem obvious y self-evident, as if they were natural phenomena belonging to the world 'out there'... domination is stabilized by making it impossible to imagine more symmetrical social relations". (Cfr. S. Marks, The Riddle of All Constitutions: International Law, Democracy y the Critique of Ideology, OUP, 2000, at 22).

26 For the main arguments underlying such link, see: SIWI \& World Health Organization [WHO], Driving Development By Investing In Water And Sanitation, SIWI-WHO, 2006.

27 The 1992 Rio Earth Summit opened the space for the formal presentation of the Dublin Principles of water resources management. Indeed, around 500 government-designated experts from 100 countries and representatives of 80 international, intergovernmental and non-governmental organizations attended the International Conference on Water and the Environment (ICWE) in Dublin on 26 January 1992. They adopted the Dublin Statement which was, in turn, "commended" by states parties of the 1992 Rio Summit. The principles constitute, in practice, the corner stone of contemporary water management, and provide: P. 1 -Fresh water is a finite and vulnerable resource, essential to sustain life, development and the environment; P. 2 - Water development and manage- 
Resources Management Policy Paper (WRMPP) which marked an important change in the Bank's approach to water supply. ${ }^{28}$

Under the new policy, WB's involvement in water projects had at its core the treatment of water as an economic good, combined with decentralized management and delivery structures, greater reliance on pricing and fuller participation by stakeholders.

This meant, in practice, that the problem of water supply was not only money, but management. ${ }^{29}$ Improving water supply required not only funds allocation, but expertise in capacity building, incentives modelling, institution design, etcetera. Thus, from this perspective, water supply is a matter of global expertise in development. And the most important forum of discussion becomes, for obvious reasons, the WB, among and other IFI's. ${ }^{30}$

The underlying text of water supply as condition for development is the notion that, since national and local administrations lack the expertise in water governance, they will use water supply for political gain, which is inefficient and non-sustainable. By the same token, in a privatization context, national regulators would lack the required expertise that shields

ment should be based on a participatory approach, involving users, planners and policy-makers at all levels; P. 3 - Women play a central part in the provision, management and safeguarding of water; and, P. 4 - Water has an economic value in all its competing uses and should be recognized as an economic good.

28 WB. Water Resources Management: A World Bank Policy Paper, WB Policy Paper $12335,1993$.

29 For the further detail on the importance and impact of the WRMPP see, generally, WB, Water Resources Sector Strategy: Strategic Directions for World Bank Engagement, WB Policy Paper 28114, 2004. But see the conflicting view contained in the UNDP's 2006 Human Development Report, which argues that poverty, power and inequality are at the heart of the problem. (Cfr. UNDP, 2006 Human Development Report "Beyond Scarcity: Power, Poverty and The Global Water Crisis", Palgrave Macmillan, 2006).

30 Such policy approach has remained largely unchanged. Nonetheless, it has grown specialized through intense division of labour within WB, especially in the Water Supply and Sanitation Board (WWS). Considering that division, and following the "good basin management principles", a Water Resources Management Group (WRMG) was created in 2000, bringing together specialists from the "stakeholder sectors" (water and sanitation, hydropower, irrigation and environment), the lead water resourcespecialist from each region, the water leaders from the World Bank Institute, IFC, and the GEF Secretariat, as well as a representative from the Legal Department. 
them against being "captured" by political interests. ${ }^{31}$ Thus, it is necessary that IFI's provide guidance and expertise, in order to prevent politicians from jeopardizing development of the whole country.

\section{B. Water supply is a matter of human rights}

Intimately related to the former is the redefinition of water supply as a matter of human rights. This move is perhaps best understood in the framework of the "human rights based approach to development" (HRBA). ${ }^{32}$ HRBA originated as a reaction to neo-liberal development policies, such as the above mentioned Water Resources Management Policy Paper, which were supported by the most influential IFI's in the1990's. The idea, in essence, was to introduce a "human face" to development, by tying aid policy to human rights as a normative value.

In this way, development goals could be framed in legal language, and could be, thus, judicially adjudicated. The move was featured as a change from "charity" to "empowerment", and came to be yet another wave of "expert consensus" in development policy, as applied by IFI's and donor agencies to aid recipient states from Albania to Zimbabwe. ${ }^{33}$

For the purposes of this paper, HRBA meant that water supply could be reframed not only as a development issue, but also, and most importantly, as a human rights issue. Being normatively based, this move implies a strong critique of the strict economic approach to water governance: it appeals to allegedly unmovable criteria (human rights) in order to assess development policy, not in its efficiency or results, but on its legality. And this is possible, because HRBA argues matters of principle: re-

31 On regulatory capture, $c f r$. R. Posner, "Theories Of Economic Regulation", 5 Bell J. of Economics and Management Science, 1974, 335; G. Becker, "A Theory of Competition Among Pressure Groups for Political Influence", 98 Quarterly Journal of Economics, 1983, 371; J.J Laffont \& J. Tirole, "The Politics of Government Decision Making. A Theory of Regulatory Capture", 106 Quarterly J. of Economics, 1991, 1089.

32 This introduction is based on: S. Seppänen, Possibilities and Challenges of the Human Rights - Bases Approach to Development, Erik Castrén Institute Research Reports, 17, 2005, at 10 .

33 Prior waves of consensus include the Harrod-Domar model, the Rostow model, some elements of the Prebischean center-periphery model and a quite long etcetera. See: W. Easterly, The Elusive Quest of Growth: Economists' Adventures and Misadventures in the Tropics, MIT Press, 2002. 
distribution, scarcity of resources and second bests do not belong to its vocabulary.

Now, the move to human rights is performed both directly and indirectly. Indirectly, the standard argument refers to water scarcity and underscores water importance to fulfil human rights expressly recognized in international law. ${ }^{34}$ In this sense, water is presented as essential to fulfil the right to life, to health and to a safe environment, among others. ${ }^{35}$

In more recent times, a more direct legal argument has been presented, through the notion of an independent human right to water. The premise of such argument is twofold: on one hand, reference is made to the three international human rights provisions that include express mentions to water: article 14 of the Convention on the Elimination of All form of Discrimination Against Women, article 24 (2.c) of the Convention of the Rights of the Child and article 14 (2.c) of the African Charter of the Rights and Welfare of the Child. ${ }^{36}$

These provisions give the "hard-law" bite to the second premise of the argument:

ECOSOC's General Comment 15 on the Covenant on Social, Economic and Cultural

Rights. ${ }^{37}$ Indeed, according to ECOSOC:

The human right to water entitles everyone to sufficient, safe, acceptable, physically accessible and affordable water for personal and domestic uses. An adequate amount of safe water is necessary to prevent death from dehydration, to reduce the risk of waterrelated disease and to provide for consumption, cooking, personal and domestic hygienic requirements. ${ }^{38}$

Joining these two elements, the argument for a human right to water is advanced. As a consequence, the natural context for discussions on

34 Cfr. S. M. A. Salman \& S. McInerney-Lankford, The Human Right to Water: Legal and Policy Dimensions, WB Publications, 2004.

35 Cfr. J. Scanlon, A. Cassar \& N. Nemes, Water as a Human Right?, IUCN Environmental Law \& Policy Paper 51, 2004, concluding that current international law does not provide for an independent right to water.

36 OAU Doc. CAB/LEG/24.9/49 (1990), entered into force Nov. 29, 1999.

37 ECOSOC, General Comment 15: The Right to Water, U.N. Doc. E/C.12/2002/11 (2002).

38 Idem. 
water supply becomes the established human rights commissions, panels and, eventually, courts.

Such is the effect of a HRBA in water policy. If water supply is framed as a human rights problem, then the result is empowerment of those who hold the expertise in human rights. The dream of litigation and adjudication of development policies (e. g. water supply) implies that lawyers and judges will eventually become the key players in the water game.

For instance, the UN Human Rights Council (UNHRC) adopted in November 2006 its Decision 2/104, requesting the Office of the United Nations High Commissioner for Human Rights (OHCHR) to conduct a study on the relevant human rights obligations related to equitable access to drinking water and sanitation.

Accordingly, the OHCHR conducted in may 2007 a three day consultation in Geneva, where governmental, nongovernmental and industry experts met to discuss. ${ }^{39}$ Such consultations were duly included in the report presented to the UNHRC by the OHCHR in August 2007.40

Water supply, in this context, becomes a matter of stakeholders and treaty interpretation, to be discussed in Geneva between experts of human rights law and human rights policy.

Likewise, water supply is also reframed as a political rights issue. Indeed, Dublin's Second Principle is clear to state that "water development and management should be based on a participatory approach, involving users, planners and policy-makers at all levels".

On these grounds, good water governance involves bestowing all parties with the right to be heard, to participate in the decision-making process and to question certain decisions involved with the service provision.

Water supply becomes an issue of transparency, accountability and even independent judicial review, which are to be exercised not only $v i s-a$-vis States, but also in the relation of consumers with private parties

39 OHCHR. Consultations on Human Rights and Access to Safe Drinking Water and Sanitation, Geneva, 11 May 2007, UN Office Geneva. Available at: www.ohchr.org/en glish/issues/water/docs/consultationReportmay07.pdf, last visit: 03.10.2007.

40 Report of the [HCHR] on the scope and content of the relevant human rights obligations related to equitable access to safe drinking water and sanitation under international human rights instruments, UN Docs. A/HRC/6/3 (2007). 
(or public - private partnerships) that provide the service in a privatization context. ${ }^{41}$

Thus, parallel to HRBA, this move frames the issue of water governance in a set of legal norms which bestow certain rights to individuals. Decision making power is transferred to instances whose authority derive from their knowledge of the law, in general, and human rights in particular.

Clearly, then, legalization of the water governance through human rights law enforces the political/expert dichotomy. Water is too important to be left to politicians. It is important to empower individuals with a right to water, because that right is legal, not political. And even better: it derives from international law.Therefore, water access is not only safely taken away from politics and delivered to adjudication, but it is delivered to international adjudication. Such adjudication is the opposite of micro-domestic political struggle: it is international rational decision making in grand scale.

\section{Water supply is a business}

GWG's external boundary is further framed by the redefinition of water as a service industry, in the terms of international trade law and the law of foreign investment. ${ }^{42}$ As is well known, the late 80 's marked a worldwide shift towards privatization of publicutilities. During the

41 Cfr. B. Morgan, "Turning Off the Tap, Urban Water Service Delivery and the Social Construction of Global Administrative Law" 17 EJIL, 2006, 246; also: B. Morgan, "Global Business, Local Constraints: The Case Of Water In South Africa", in: N. Woods (ed.), Making Global Regulation Effective, OUP, 2006.

42 Furthermore, though the debate of water as a business in commonly focused on the services perspective, there are circumstances where water is seen as an internationally traded good. As far as I am aware of, the first comprehensive debate of such possibility sparked in the early 1990's, when Canada voiced concerns that NAFTA would compel it to export its water to the US if so demanded. In all truth, the concern was not unfounded, and a September 1993 NAFTA statement expressly worded out the duty to export freshwaters in their "natural state" (Cfr. H. Mann, "International Economic Law: Water for Money's Sake?", I Seminario Latino-Americano de Politicas Publicas em Recursos Hidricos, Brasilia, 22 September 2004 (at: www.iisd.org/pdf/2004/investment_water_economic_law.pdf), last visit: 02.10 .2007 . At any rate, international trade of water as a good has a marginal effect when compared to the impact of the services rhetoric in advancing the expert/political dichotomy and can, thus, be comfortably integrated for the purposes of this paper. 
1990's, transport, energy, telecommunications and water supply, among others, were progressively liberalized in both the developed and the developing world.

Privatization activities in OECD countries came from USD 16.1 billion in 1990 to USD 67.1 billion in 2000, with a peak of 100 billion in 1998. In developing countries, the same activities came from USD 15 billion in 1990 to USD 90 billion in 2000, with a peak of 118 billion in 1997. ${ }^{43}$ To grasp the size of these operations, consider that the historical peak of aggregate development aid by all OECD countries is USD 106.8 billion; ${ }^{44}$ that is, USD 11.2 billions less than the historical peak of privatizations in the developing world.

Effects of such trend are today subject of heated debate. Though we have a fairly comprehensive theoretical framework of what those effects may be, ${ }^{45}$ empirical studies seem to be in short supply. In Noll's apt words, in this case, "as in much of applied microeconomics, the theory to fact ratio is far too high", ${ }^{46}$ and closure to the discussion of who wins and who loses with utilities privatization seems far away.

Yet, it is clear that such process implied a reframing of water supply. The idea of water as a service exclusively supplied by the state was questioned, and a competition based rationale was introduced. ${ }^{47}$ Water supply was understood as a standard network industry, not that different from

43 Source: A. Limi, "Rethinking Privatization and Economic Development: A Sampling of Evidence". Japan Bank for International Cooperation (JBIC) Institute, Working Paper num. 9, May 2003.

44 Achieved in 2005, including the Paris Club debt relief transactions for Iraq and Nigeria. Source: OECD. "Development aid from OECD countries fell 5.1\% in 2006", at: www.oecd.org/document/17/0,3343,en_2649_37455_38341265_1_1_1_37455,00.html, last visit: 02.10 .2007 .

45 One of the best introductions to the main issues still is: J. Vickers \& G. Yarrow, Privatization: An Economic Analysis, MIT Press, 1988, and J. J Laffont \& J. Tirole, "Privatization and Incentives", VII J. of Law, Economics, and Organization, 1991, 84.

46 R. Noll, "Telecommunications Reforms in Developing Countries", Stanford Univ. Department of Economics, Working Papers, 1998, at 16. But see: S. J. Wallsten, An Empirical Analysis of Competition, Privatization, and Regulation in Africa and Latin America, World Bank Working Paper Series [WPS] 2136, 2000, and G. R. G.Clarke \& R. Cull, The Political Economy of Privatization: An Empirical Analysis of Bank Privatization In Argentina, WPS 1962, 1998.

47 Cfr. T. Balance \& A. Taylor, Competition and Economic Regulation in Water. The Future of the European Water Industry, IWA Publishing, 2005. 
network telecommunications or railways, ${ }^{48}$ featuring particularly high capital requirements and sunk costs. ${ }^{49}$

In this context, it became apparent that the legal regime developed for international trade and investments should be also applied to water supply. Thus, water was reframed as a "service" and regulated internationally as such. ${ }^{50}$ Such reframing implied, in turn, moving water supply debates to a novel arena, composed essentially by the WTO, on one hand, and WB's International Centre for Settlement of Investment Disputes (ICSID), on the other. ${ }^{51}$

The way in which such move reinforces the politics/expertise dichotomy is clear enough. High sunk costs related to water supply pose an irresistible temptation to opportunistic national governments, whose poli-

48 Cfr. generally, J. Gómez-Ibáñez, Regulating Infrastructure. Monopoly, Contracts and Discretion, Harvard UP, 2004.

49 A cost is sunk if it has been incurred and cannot be recovered in any significant degree. In water supply, costs of network development and expansion are sunk: once the pipes are set underground, there is little that the investor can do to recover those costs, even if she wants to pull out of the project.

50 Under the General Agreement on Trade in Services (GATS), water supply is a Mode 3 Environmental Service, which may be included under D sub sector of Section 6 of Document MTN.GNS/W/120 (which is a descriptive tool of service classification, comprised of 12 core sectors and 160 sub-sectors). This, in turn, implies that specific commitments may be adopted in the water supply service share of a national market, especially (and controversially) regarding market access. However, a State may be a part of the World Trade Organization (WTO), and still be bound only by Sections I and II of GATS, while acquiring very limited compromises (by opening very few sectors) under the rest of the Agreement. Taking these commitments is not mandatory and no state has yet done so for urban water supply (Source: WTO www.wto.org/english/tratop_e/serv_e/gats_fact fiction8_e.htm, last visit: 03.10.2007).

51 ICSID is an autonomous international organization belonging to the WB group. All of ICSID's members are also members of the Bank. ICSID was created in 1966, and provides facilities for the conciliation and arbitration of disputes between member countries and investors who qualify as nationals of other member countries. It should be noted that recourse to ICSID conciliation and arbitration is voluntary. Of course, once the parties have consented to arbitration under the ICSID Convention, neither can unilaterally withdraw its consent. More importantly, all ICSID Contracting States, whether or not parties to the dispute, are required by the Convention to recognize and enforce all ICSID arbitral awards. As of May 2007, 156 had signed the ICSID Convention, of which 144 have deposited the instrument of ratification (Source: ICSID. <www.worldbank.org/icsid/about/about.htm>, last visit: 03.10.2007). 
tical motives would lead to (illegally) take over foreign investment and/or to restrict foreign access to the market service. ${ }^{52}$

However, local judiciary cannot be trusted: it lacks the expertise and, at any rate, the political independence from government to adjudicate such cases. Local politics, in this narrative, is the risk; and international regulation is the solution. Hence, it is necessary to appeal to global judicial expertise, which is not intimidated by locally powerful (but globally weak) politicians.

\section{Urban water supply is an environmental issue}

Finally, the fourth wall of GWG's external border is the redefinition of water supply as an environmental problem. Although fairly intuitive, this redefinition is particularly effective at advancing the experts/politics dichotomy, through the strategic use of the "hydrologic cycle".

The "cycle" refers to the process whereby water in the seas and lakes evaporates into the air, condensates and then falls as precipitation: part of it falls back on the seas and lakes, part of it on the soil. Much of the latter, in turn, soaks into the ground as infiltration, joining ground-water lines which feed seas and lakes that again evaporate into the air, just to fall as precipitation and, like that, ad infinitum. The water cycle has no beginning and no end; the part depends on the whole and the whole depends on each of the parts. ${ }^{53}$

This delicate balance is made instrumental for advancing the expertise/politics dichotomy. Water supply is liable to affect the whole water cycle, and thus have an important impact in the environment. Humans and ecosystems share the same water; however, hydrologists draw the line between "green water" (the water flow that supports plant production) and "blue water" (the water flow that is needed for human welfa-

52 "Government opportunism" or "opportunistic regulation" is one of the main arguments for strong protection of property rights in foreign investment law. For the standard argument, cfr. J.M Glachant \& E. Brousseau, The Economics of Contracts: Theories and Applications, CUP, 2001, at 467.

53 Cfr. NASA Observatorium, The Hydrological Cycle, at: http://observe.arc.nasa. gov/nasa/earth/hydrocycle/hydro1.html, last visit: 03.10.2007. 
re) ${ }^{54}$ Normally, assessments of the water crisis focus on blue water, and neglect green water. ${ }^{55}$ And yet, as human activities and ecosystems depend on the same water, trade-offs are inevitable: striking a balance between the sustainable use of green and blue water is, then, the central issue of water supply as an environmental issue.

Thus framed, the issue becomes a matter of negotiation between the "environmentalists" and the "developmentists", to be carried out in forums, panels and high level meetings, where experts of each side get together and try to find a middle point that will benefit the world as a whole. ${ }^{56}$ Water as an environmental problem is, at the bottom, a problem of two contesting expertises, which try to find a middle ground in order to maintain their own relevance in the creation of an international water policy.

Thus, in this version of the story, the right thing to do is for experts to put aside their differences and hammer down a way out of the conundrum. If not, political calculations would take over the discussion, and the balance would be a worst case scenario: polluted underdevelopment.

\section{IT TAKES TWO TO TANGO. EXPERTISE AS A FORM OF POWER}

As we have seen, GWG is not a grand conspiracy to take over our water. ${ }^{57}$ It is, rather, the space that results from the interaction between apparently unconnected discourses, wherein a relatively coherent form of power is exercised over water resources. A form of power that is, in turn, defined specifically in reference to the expertise/politics dichotomy.

By defining its external boundaries through such dichotomy, GWG engages in a redistributive process whose ultimate consequence is the empowerment of experts. GWG takes power from a group of decision makers who are left out of the loop (the "politicians"), and gives it to

54 F. Moberg \& V. Galaz, Resilience: Going from Conventional to Adaptive Freshwater Management for Human and Ecosystem Compatibility, Swedish Water House Policy Brief Nr. 3, SIWI, 2005.

55 Cfr. generally, R. C. Griffin, Water Resource Economics. The Analysis of Scarcity, Policies, and Projects, MIT Press, 2006.

56 See, for instance: M. Falkenmark \& H. Tropp, Ecosystem Approach and Governance: Contrasting Interpretations, SIWI, 2005.

57 Cfr. e.g. L. Wallach, "Why does the WTO want my water?", at: www.common dreams.org/views03/030502.htm, last visit: 02.10.07. 
another (the "experts") who are thus placed in the centre of decision making process.

But who are these experts? What is, indeed, expertise? We need to go beyond the dichotomy's rough Manichaeism of defining an expert as he who is non-political. Expertise is not an attribute, but a relation. It describes a specific form of power that is exercised by the "expert" over the "layman". Such form of power differs from others in the all-important role played by knowledge: expertise is characterized by the presence of knowledge that is held expert and ignored by the layman, which is deployed creating a power relation between them, as depicted on figure 2 , below.

\section{Expertise as a relation}

This case has been elaborated by anthropological work done on authoritative knowledge, specifically in the area of medical anthropology. Presenting the results of her study on prenatal care in a large U.S metropolitan area, Lazarus explains that there are two opposing trends in medical anthropology regarding the doctor-patient relation: the "explanatory models approach" and "critical medical anthropology". ${ }^{58}$

For my purposes, the critical approach is of interest. According to it, doctor - patient relations can be read within a more general framework of power, knowledge and domination. Such relations are interactions based on power, featuring structural asymmetries that favour the doctor. The doctor controls knowledge and technology; she does not negotiate or share her diagnosis with the patient: the patient is co-opted by her. Medicine, then, is a mechanism of social control, which can be analysed as any other mechanism of domination. ${ }^{59}$

This critical approach allowed for further developments in framing medical knowledge in power terms. Analyzing the role of midwives at

58 E. S. Lazarus, "Theoretical Considerations for the Study of Doctor - Patient Relationship: Implications of a Perinatal Study”, 2 Medical Anthropology Quarterly, 1988, 34.

59 Foucault is the standard reference in such line of reasoning. Cf, generally: M. Foucault, Naissance de la Clinique: Une Archéologie du Regard Médical, PUF, 2003 [1962]. Significantly, Lazarus refers to this work neither here nor in her other works on critical medical anthropology. Cfr., e.g: E. S. Lazarus \& G. Pappas, "Categories of Thought and Critical Theory: Anthropology and the Social Science of Medicine", $17 \mathrm{Me}$ dical Anthropology Quarterly, 1986, 136. 
Pejehun District in Sierra Leone, Jambai and McCormack ${ }^{60}$ argue that medical practitioners are able to command uncoerced obedience to their patients, based on a legitimacy bestowed upon them by any particular mix of Weber's three kinds of legitimacy: rational-legal, traditional and charismatic.

The point underpinning Jambai and McCormack's observations is that authoritative knowledge is such because it is legitimate, in the sense that it provokes uncoerced obedience from the patients. They understand authoritative knowledge, and the relevance of expertise, as a function of legitimacy: in order to be truly authoritative, the expert has to be legitimate.

Note, however, that the source of legitimacy does not alter the relation of expertise. Indeed, Jambai and McCormack seem to suggest that, although it is clear that experts need to be legitimate, which specific kind of legitimacy, they are invested with is not of the essence. Western doctors and midwives both structure a power relation of expertise with their clients. And yet midwives can be traditionally legitimate, but also rational-legally legitimate, if they hold a government card of approval for their work (as may happen in Sierra Leone).$^{61}$ European medicine, on the other hand, is commonly rational-legally legitimate, but may be traditionally legitimate in certain contexts (like Western European states).

This goes to a broader point. If expertise is a power relation that is not altered by the source of its legitimacy, then a methodological line can be drawn. It is possible to usefully discuss expertise as a separate issue from the legitimacy of expert rule. This line, as is shown in the lower part of figure 2, does not imply that legitimacy is not important for the structure of expertise. On the contrary, it is a must. However, dwelling in a specific form of legitimacy is not required to make sense of expertise in GWG and may, actually, hinder more relevant discussions, as will be argued in the third section of this paper.

60 A. Jambai \& C. MacCormack, "Maternal Health, War and Religious Tradition: Authoritative Knowledge in Pejehun District, Sierra Leone", 10 Medical Anthropology Quarterly, "The Social Production of Authoritative Knowledge in Pregnancy and Childbirth", 1996, 270.

61 Idem. 
Figure 2

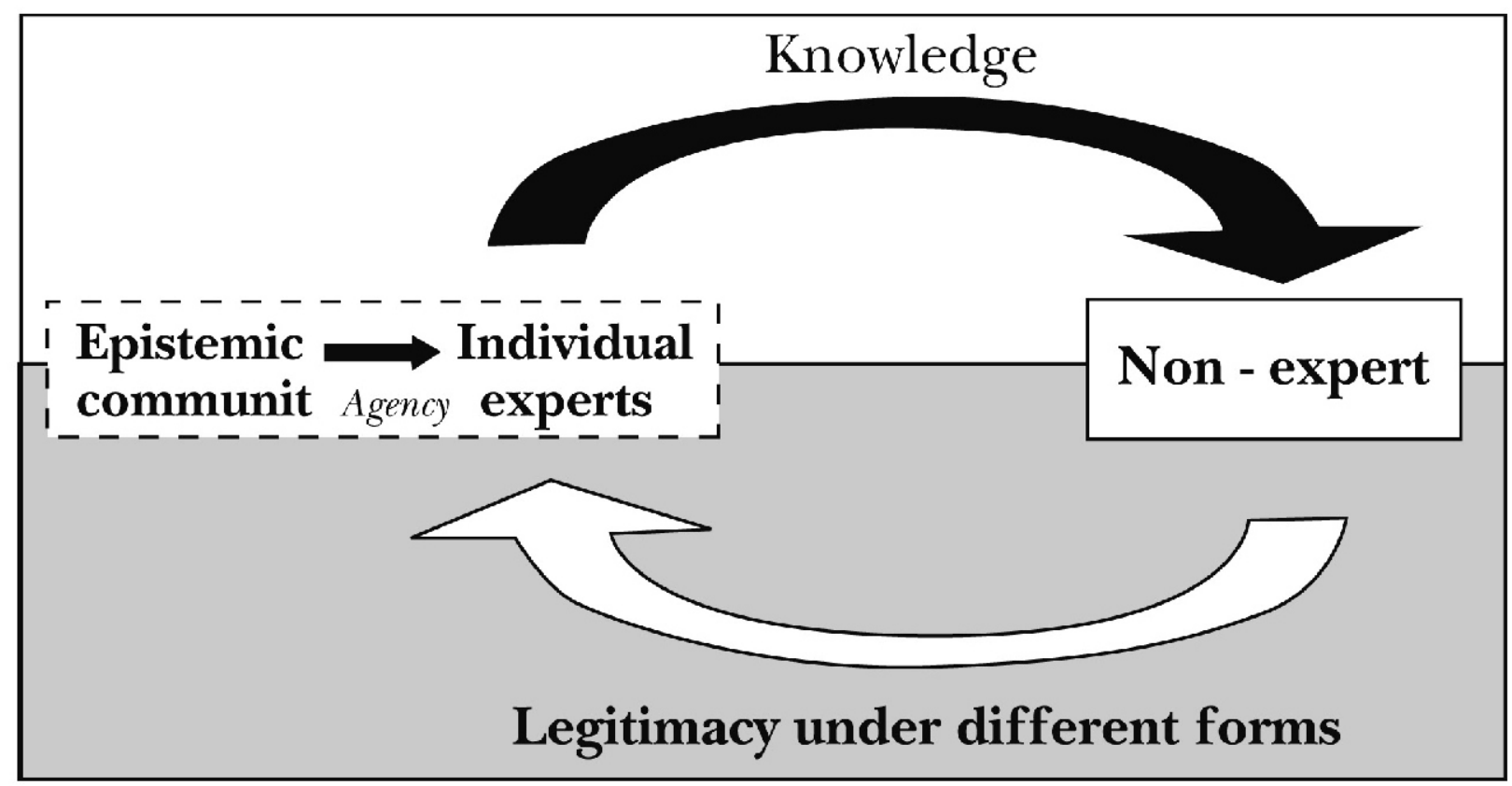


Now, bracketing legitimacy from the discussion may lead to a dangerous dead-end. There is no objective amount of knowledge or certain number of publications that will make anyone an "expert". Therefore, without the external normative criteria of legitimacy, we risk ending up with an apologetic definition of "expert": expert is who expertise does. And clearly, the circularity of this approach will not take us far in understanding the role of expertise in GWG.

\section{Systemic agency}

There is one way of breaking that circle. An expert can be understood to be the right person, in the right place, at the right time. That person can be understood to have, in Sahlins words, systemic agency. ${ }^{62}$

Indeed, Sahlins analyses individual actions that are liable to affect social collectivities (i.e., "historical agency"), by making an interesting parallel between Napoleon and baseball player Bobby Thompson. He argues that although both, as individuals, had the ability to affect the collectivity, they did so in a different way: while Thompson deployed conjunctural agency, Napoleon deployed systemic agency. ${ }^{63}$

Systemic agency refers to the "institutional empowerment of the great man"; 64 that is, the relation whereby larger networks of society rely on one person of authority. Because such authority is a relation between people, the issue is a matter of cultural order. Social networks bestow authority on the individual, who is thus placed in spot from where she is able to deploy historical agency.

62 M. Sahlins, Apologies to Thucydides. Understanding History as Culture and Vice versa, U. of Chicago Press, 2004, at 155.

63 Ibidem. Bobby Thompson hit the famous "shot heard around the world" home-run, which gave the New York Giants the 1951 National League pennant over the Brooklyn Dodgers. Sahlins' example is especially apt because this is, perhaps, the most famous shot in baseball history. However, despite it being nothing short of a historical landmark (for example, it opens D. Delillo's novel Underworld, NY: Scribner, 1997), it rests on the shoulders of a man who basically disappeared soon after. Thompson was sent to the Milwaukee Braves in 1954, where he broke an ankle. Sahlins' point is fatefully made by the fact that it was precisely that broken ankle which allowed Hank Aaron to join the Major League in replacement for Thompson, and meet his place in history as home run king for 33 years, until 2007.

64 M. Sahlins op. cit., note 62, at 155. 
Certainly, the individual's particular traits are relevant. However, historical agency does not depend on them. In this sense, even if one believes that Napoleon was a great man, his agency does not derive from him being a great man. It derives from the social network's reliance on him. Once in that position, whatever he does is history.

Expertise in GWG features the same sort of agency. Even if they do actually know more than the lay man, experts' agency does not depend on their own knowledge, because there is no objective threshold that defines them as experts. It depends, rather, on their location with regards to the social network that relies on them as experts.

\section{Three consequences}

There are three consequences of this approach. First, as we can see in figure 2, expertise is a general equilibrium system. ${ }^{65}$ Even if it looks at first sight as a monolithic phenomenon (an "attribute"), expertise is actually a function of the interaction between several variables, all of which converge in the individual expert. People, knowledge and legitimacy relate in such a way that they end up framing the notion of expertise in a given time. Today's experts are not be tomorrow's. If one variable changes, the point of equilibrium will move, and expertise will be reframed.

This, in turn, leads to the second consequence of expert's systemic agency. If expertise is a general equilibrium system, then experts are prisoners of their own expertise. The key point issue here is discretion: experts are limited in their freedom by their expertise. ${ }^{66}$ An expert may want to follow her conscience against her expertise, but then again she is not moving the variables that set the general equilibrium. Thus, she does not create a new point of equilibrium; i.e., new expertise. Rather, she will be discarded as an expert, and other individual will take over her systemic agency.

But, discarded by whom? Such question introduces the third consequence of this approach. The notion of systemic agency moves the spot-

65 For the notion of general equilibrium systems as a standard critical move, $c f r$. Duncan Kennedy, "A Semiotics of Critique”, 22 Cardozo Law Review, 2001, 1147 at 1151.

66 This point has been made before in D. Kennedy, op. cit., note 3, at 12. 
light from the expert as an individual, to the social network providing her with systemic agency.

However, there is no single college of GWG expertise. Rather, and along the lines of the four redefinitions that frame GWG, it is possible to talk of at least four groups of experts who are empowered: development specialists, human rights lawyers, international trade lawyers and environment specialists.

Each of these groups, which can be seen at the left side of Figure 2, constitutes what Peter Haas called an "epistemic community"; 67 that is, a "network of knowledge-based experts or groups with an authoritative claim to policy-relevant knowledge within the domain of their expertise". 68

Such network is united by four characteristics: (1) "a shared set of normative and principled beliefs", which provide a value-based rationale for the social action; (2) "a shared causal beliefs", which then serve as the basis for elucidating the multiple linkages between possible policy actions and desired outcomes; (3) "shared notions of validity" for weighing and validating knowledge in the domain of their expertise; and (4) "a common policy enterprise" to which their professional competence is directed, presumably out of the conviction that human welfare will be enhanced as a consequence. ${ }^{69}$

These networks are the ultimate source of systemic agency, as depicted also in figure 2. Each one of them empowers a different group of experts, which leads to competing epistemic communities within WGW, providing competing systemic agencies. Thus, the move towards expert rule does not necessarily imply hegemonic understanding of water is-

67 Ernst M. Haas (incidentally, Peter's father) has also used the concept of epistemic communities, most importantly in his When Knowledge is Power, U. of California Press, 1990. I will, however, focus here in Peter Haas' development of the issue as presented originally in "Introduction: Epistemic Communities and International Policy Co-Ordination" and "Banning Chlorofluorocarbons: Epistemic Community Efforts To Protect Stratospheric Ozone" 46 International Organizations, 1992, 1 and 187; and then elaborated in:"Obtaining International Environmental Protection Through Epistemic Consensus", in: I. Rowlands \& M. Greene (eds), Global Environmental Change And International Relations, Macmillan, 1992, and "Social Constructivism and the Evolution of Multilateral Governance", in: J. Hart \& A. Prakash (eds), Globalization and Governance, Routledge, 1999.

68 P. Haas, "Introduction...", op. cit., note 67 , at 3.

69 Ibidem. 
sues. On the contrary, it implies clashes of between epistemic communities, which are, nonetheless, prisons for their own members.

\section{Expert power in action}

The foregoing description hints one of the greater difficulties in understanding expert power in GWG: the fact that we simply cannot see it. Expert power is invisible at its most effective, thus making it particularly difficult to apprehend. There will be no smoking gun here. There cannot be: if there is, we are not talking about expertise.

Indeed, expertise is an example of what Lukes calls the "three-dimensional view of power". ${ }^{70}$ In his account, traditional ways of understanding power are fruitless because they see "power" only if A makes B do something against B's will. That is, they focus too much in individuals, active behaviour and conflict, leaving outside some of the most striking power practices.

For Lukes, the most effective forms of power are deployed not through decision making, but through non - decisions; not through the action of one individual, but through the mobilization of collective bias; not through conflict, but through willing compliance.

Expertise in GWG is deployed in such way. Expert's role is, essentially, to frame issues for policy-makers: they reveal hidden cause-effect relations in complex issues and help policy makers define their self-interest. Under uncertainty and perplexed by technical complexity, policy makers turn to the individuals sanctioned by the relevant epistemic community, who then provide certainty by explaining what causes generate which effects. ${ }^{71}$

Think of the "Jeffrey Sachs legend" and his "shock therapy" in Poland, Russia and Bolivia in the 1990's. ${ }^{72}$ His is the poster image of economical expertise: an individual whose mysterious knowledge (of economics) enables him to frame the issues to policy makers, and propose

70 S. Lukes, Power: A Radical View, Palgrave-Macmillan, 2005 [1974], at 58.

7171 P. Haas, "Introduction...", op. cit., note 67, at 9.

72 Two documentaries are useful to illustrate in detail the image of Sachs as an expert depicted here: Dutch Tagenlicht's Jeffrey's aanpak: het einde van armoede? (Cfr. http://www.vpro.nl/programma/tegenlicht/afleveringen/24214614/) and American PBS', Commanding Heights: The Battle for The World Economy (cfr. http://www.pbs.org/wg bh/commandingheights/). 
solutions. Policy makers, in turn, turn to him for advice, and follow it carefully. ${ }^{73}$

Through this framing process, experts effectively prevent other issues to appear in the policy agenda. Such exclusion amounts, in Lukes terms, to a "non-decision", which is made possible by the mobilization of the epistemic community through systemic agency. Deployment of expert knowledge, thus, feels natural. It does not feel imposed or conflictive; on the contrary, it appears as the only logical option. Expert knowledge in action, in short, is B willing to do something, because he conceives no other choice.

\section{ASSESSING GWG: EXPERTISE AND THE LIMITS OF THE CALL FOR MAJORITARIAN RULE}

Let us go back to the governance of water resources. If it is true that GWG is structured around the notion of expertise, then what we are facing is an essentially controversial form of power over natural resources.

Indeed, water's exceptional importance suggests that nothing short of a "water democracy" is acceptable. ${ }^{74}$ It sounds right for people to have the possibility of taking part of the decisions over their natural resources. It is their right and GWG should not stand in their way. ${ }^{75}$

Let's start, though, by watering down the unqualified call for "democracy". As is well known, "democracy" is a contested concept, and can be understood as a procedural or as a substantive notion. ${ }^{76}$

Procedural democracy implies that the democratic system is exhausted in a set of procedures that include, typically, periodic popular elections. Substantive democracy, on the other hand, submits that democracy is more than simple procedures: it implies a certain "core of political

73 For further detail of such dynamics, $c f r$. S. F Moore, "The International Production of Authoritative Knowledge: The Case of Drought Stricken West Africa", 2 Ethnography, 2001, 161.

74 Cfr. V. Shiva, Water Wars: Privatization, Pollution and Profit, Southend Press, 2002.

75 Ibidem, at 35. Shiva enounces the "9 principles of water democracy", which have been taken as a spearhead for water activism by several NGO's and grassroot organizations.

76 G. H. Fox and G. Nolte, "Intolerant Democracies", in G. H. Fox \& B. R. Roth (eds.), Democratic Governance and International Law, CUP, 2000, 400. 
rights" that enables participation and cannot be derogated by majority vote.

There are no substantive decisions over water that could be labelled as inherently "democratic". Rather, democracy in this context seems to refer to a decision-making process. And, since we lack "water elections", majority rule appears as the most appropriate criteria for assessing how democratic GWG is.

\section{Economism}

This issue has been tackled before. The majority rule test for GWG coincides with the notion of "economism", as proposed by Teivainen. ${ }^{77}$ Indeed, analysing the political economy of Perú in recent years, Teivainen notes the introduction of a boundary between economics and politics. ${ }^{78}$ Economics is presented as an essentially neutral and scientific matter, to be handled by economic experts. Therefore, issues of such nature are not considered to be the object of majoritarian rule: they are defined as apolitical, beyond power struggles, and treated consequently. ${ }^{79}$

This move is not performed illegally. On the contrary, it is advanced through constitutional rearrangements which give way to the "constitutional politics of economism"; that is, the constitutional layout that "places limits to the majority rule in order to shield issues defined as economic from the reaches of majority rule". 80

Such framework is evidently analogous to GWG's characteristic dichotomy. And yet, "economism" implies one further normative step: issues are being shielded from majoritarian rule and this is a bad thing.

77 T. Teivainen, Enter Economism, Exit Politics: Experts, Economic Policy and the Damage to Democracy, Zed Books, 2002. "Economism" as an expression can be traced back to Lenin's 1902 pamphlet What is to be done?, where the term is derogatorily used to label the belief that "that the working masses themselves have not yet advanced the broad and militant political tasks which the revolutionaries are attempting to 'impose' on them; that they must continue to struggle for immediate political demands, to conduct the economic struggle against the employers and the government". (Cfr. V.I Lenin, "What is to be done?", 5 Lenin Collected Works, Foreign Languages Publishing House, 1961, at 440; see also: "A Talk with Defenders of Economism", ibidem at 313. Public domain: Lenin Internet archive, www.marxists.org/archive/lenin/index.htm, last visit: 21.10.2007.

78 T. Teivainen, op. cit., at 1.

79 Ibidem, at 10.

80 Ibidem, at 18 . 
Such is the normative test that has been applied to problem of expertise: is GWG shielding water resources from majoritarian rule? If it is, then that move should be resisted.

The first question of the test has been answered. Expertise as a power relation implies, almost by definition, that there is no majoritarian rule. Even in the presence of a majoritarian vote investing the expert with legitimacy, that vote would not be a case of majoritarian rule, but of expert rule legitimized by a majority.

This difference is of importance. If we remember figure 2, legitimacy is only one of the variables that define the general equilibrium of expertise. If, despite a majoritarian vote, a decision still requires the agency deployed by the relevant epistemic community, then there is no majoritarian rule, but expert rule. The latter may include majoritarian legitimacy, but it necessarily excludes majoritarian rule.

Consider the case of the "participatory budgets" (PB), famously implemented in Porto Alegre (Brasil) and other Latin-American cities: although clearly beneficial for creating a strong democratic culture, PB's are haunted by the ghost of macro economical imbalance. Under that argument, majority opinion is always filtered by governmental experts who, after a festive wish-list by grass root organizations, proceed to sort and frame priorities in "primary" and "secondary" budgetary matrixes. It is those matrixes, and not the majoritarian demands, that are discussed and approved by legislatures. ${ }^{81}$ Even though there is majoritarian input and approval of experts'decisions, the decision is still ultimately taken by the expert: there is, in strict sense, no majoritarian rule.

81 Budgetary matrixes (Matriz Orçamentária) are required under article. 2, par. IV, section IV, of Federal Law 4.320 (1964) concerning budgeting process (Lei 4.320, Estatui Normas Gerais de Direito Financeiro para experts'decisions, the decision is still ultimately taken by the expert: there is, in strict sense, no majoritarian rule. elaboração $e$ contrôle dos orçamentos e balanços da União, dos Estados, dos Municípios e do Distrito Federal). For a detailed account of the impact of budgetary matrixes in the overall participatory process in Porto Alegre, $c f$. M. Nassuno, O Quadro Administrativo na Experiência do Orçamento Participativo de Porto Alegre, $\mathrm{PhD}$ Thesis, Universidad Federal de Santa Catarina, at: www.sociologia.ufsc.br/npms/marianne_nassuno.pdf, last visit: 21.10.2007. Further, such filter's ability to allow "empowerment" without risking "wish-lists" has made the World Bank one of PB's main supporters, through its 2002 Empowerment initiative, $c f$. World Bank, Empowerment and Poverty Reduction: A Sourcebook, WB, 2002, at 33 . 


\section{The limits of majoritarian rule}

The foregoing brings us to the second part of the normative assessment. As we saw, GWG can be rightly described as "constitutional politics of water", in the sense that it shields decision over water resources from majoritarian rule. Such argument presumes that governance of water resources should be responsive to the will of the majority, but it is not being so; hence, the normative critique. It implies that, as an expert dependant system, GWG is not responsive to the interests it should be responsive to.

Such lack of responsiveness is not exclusive of GWG, but is a chronic illness of globalized regulatory frameworks. It is a form of Stewart's "problem of disregard"; that is, the fact that "global regulatory bodies disregard or give inadequate consideration to a range of important social, economic, cultural, environmental and other interests and values... impacted by their decisions". 82

How to solve that problem? A close look to that question's answer will serve as basis to see why, in the context of GWG and its heavy reliance in expert power, the call for majority rule is ineffective and counterproductive.

There are essentially three mechanisms through which the problem of disregard has been addressed: 83

1. Decision rules, which define the entities or persons who have authority to make decisions for an institution and the voting rules or other requirements for making authoritative decisions;

2. Accountability mechanisms, which are designed to protect organizational "outsiders" by influencing "inside" decision makers to give regard to their interests; and,

3. Other responsiveness-promoting measures, which are institutional measures that are neither decisional rules nor accountability mechanisms.

The call for majoritarian rule falls neatly within the first category, as it argues for the implementation of rules that would allow majoritarian

82 R. B. Stewart, Accountability and the Discontents of Globalization: US and EU Models for Regulatory Governance, Hauser Colloquium on Globalization and Its Discontents at 5, at: www.law.nyu.edu/kingsburyb/fall06/globalization/speakers_papers.html, last visit: 21.10 .2007 .

83 Ibidem, at 8. 
participation in decision making within GWG, thus forcing it to be more responsive to majority's will.

However, decision rules in general seem ineffective in the context of an expert dependant system. Indeed, the distinctive trait of expert power is its ability to frame issues, and exclude other issues from the agenda. Such exclusions are not covered by decision-making rules precisely because they are not decision-making. The most important choices taken in GWG are those that, as non-decisions, cannot be subject to rules that created under this strategy. Therefore, decision rules are futile as a means of resistance in GWG, because they targets decisions: precisely where expert power is at its least effective.

Economism, thus, accurately describes GWG. Yet, its normative agenda is not useful for a context of expert power. Focus on majority rule keeps the spotlight off non-decisions, off framing procedures and off willing compliance: precisely the circumstances where expertise is deployed at its most effective. It makes political activists demand majority rule in cases where majority rule will not have an impact. As said, it does call a bluff, but it seems to be the wrong one. ${ }^{84}$

Of course, nothing makes water governance inherently unfit for majority rule. If we can think of a global parliament (GP), then we can certainly think of an institutional arrangement for the governance of water resources. ${ }^{85}$ However, given the current legal and institutional arrange-

84 Note that this is not a problem of democratic legitimacy. Expertise is able to demand uncoerced obedience through several claims of legitimacy, other than democratic legitimacy. Therefore, arguing that GWG shields water governance from majoritarian rule does not imply that GWG is illegitimate. As said above, it merely implies that GWG is non-responsive to majority. In this context, R. Howse makes a good point in showing how the WTO is legitimate is several different (and not necessarily democratic) ways in: R. Howse, "The Legitimacy of the WTO", in: J. M. Coicaud \& V. Heiskanen (eds.), The Legitimacy of International Organizations, UNUP, 2001, 355.

85 Or even within such GP. The four redefinitions that structure GWG can be read also as four reasons why water is a global problem, making it an ideal subject-matter for a global parliamentary initiative. Specifically, virtual water is an amazing discussion that could only be pushed at the level of a GP. Virtual water is the amount of water that is embedded in food or other products needed for its production. For example, producing $1 \mathrm{~kg}$ of grain requires $1000-2000 \mathrm{~kg}$ of water; producing $1 \mathrm{~kg}$ of cheese requires $5000-5500$ $\mathrm{kg}$ of water and $1 \mathrm{~kg}$ of beef needs $16000 \mathrm{~kg}$ of water. The production of a 32-megabyte computer chip of 2 grams requires $32 \mathrm{~kg}$ of water. In this sense, in order to create incentives for water protection, one possibility could be to follow a Pigouvian rationale and propose the GP to impose taxation on virtual water. Such tax would be structured as a global 
ment and its distinctive focus on expert power, the call for majority rule is ineffective and counterproductive.

The same can be said of the second kind of mechanisms devised to solve the problem of disregard; namely, responsiveness-promoting measures. Procedures of nondecisional participation by non-experts, just as requirements of reasons giving and even notice-and-comment arrangements, all seem of limited use. Indeed, they all focus on information, comments and reasons to be given in reference to the potential decision as previously framed by experts. Thus, they seem limited to challenge precisely that sort of power. If the issue is GWG's expert rule through non-decision, then responsiveness-promoting measures are not the answer.

\section{What now?}

One more helpful way to approach the disregard problem in the context of GWG is to focus on accountability. As Lukes has aptly put it, the ultimate point of locating power is fixing responsibility. ${ }^{86}$ If locating decisions seems irrelevant in practice, then perhaps a way of effective resistance and activism is to focus on the people who are taking the decision. Accountability, and not decision - making rules, seems to be the key word in this context.

Just as expertise, accountability is also a relation. It includes, a

specified accountor, who is subject to being called to account or answer for some specified aspect or range of his conduct, and a specified account holder... who is entitled to demand and receive such an accounting, evaluate the performance of the accountor, and impose sanctions or obtain re-

tax, not that different from the so-called Tobin Tax, or Currency Transaction Tax. On virtual water, $c f r$. A. K. Chapagain \& A.Y. Hoekstra, "Virtual Water Trade: A Quantification of Virtual Water Flows Between Nations in Relation to International Trade of Livestock and Livestock Products", in: A.Y. Hoekstra (ed), Virtual Water Trade: Proceedings of the International Expert Meeting on Virtual Water Trade. February 2003, Value of Water Research Report Series, num. 12, IHE Delft, 2003, at 29. On GP, cf. Patomäki \& Teivanen, op. cit., note 6, at 78; also: H. Patomäki, "Rethinking Global Parliament: Beyond Indeterminacy", 13 Widener Law Review, 2007.

86 S. Lukes, op. cit., note 70, at 58. 
medies for conduct that falls short or, in some cases, rewards for superior performance..$^{87}$

Such structure is useful in GWG because it provides an ex-post criteria for evaluating expertise. It is not the decision taken by experts, but the effect of the cluster of decision and non-decision, which is the input for holding an expert accountable.

For this purposes, work in the global garment industry ${ }^{88}$ and refugee law, ${ }^{89}$ which focuses on the possibility of holding experts accountable based on the effects of their expertise, could be a good starting point.

Likewise, other source of accountability may be private law. GWG clearly derives from both private and public law sources. Why, then, do we obsess with public law as the only source of accountability? Concessions of water supply and the whole framework of "regulation by contract" 90 opens an opportunity for accountability in this regard which could be explored.

Alas, two caveats. Accountability as a relation seems to rely too heavily in a principal/agent structure, wherein the expert is the agent of the non-expert. In this relation, then, there is a delegation, that the expert fails to uphold when his actions are non responsive to the layman's interest. In other words: accountability as a relation seems to presume that the layman delegates, invests or bestows something on the expert, and hence the possibility of calling him accountable.

However, that is not the only case. Although non-experts do invest legitimacy in experts, the latter is also invested of systemic agency from the relevant epistemic community. Appealing to accountability, then, implies the risk of conflicting accountabilities (to the epistemic community

87 R. B. Stewart, op. cit., note 82, at 11.

88 T. MacDonald \& K MacDonald, "Non-Electoral Accountability in Global Politics: Strengthening DemocraticControl within the Global Garment Industry", 17 EJIL, 2006, 89.

89 M. Pallis, "The Operation of UNHCR's Accountability Mechanisms", IILJ Working Paper 2005/12, at: www.iilj.org/papers/IILJ2005_12Pallis.htm, last visit: 21.10. 2007.

90 Cfr. T. Bakovic, B. W. Tenenbaum \& F. Woolf, Regulation by Contract: A New Way to Privatize Electricity Distribution?, WB, 2003; for the same framework in IPR's, cfr.: M. J Radin, "Regulation by Contract, Regulation by Machine", 160 Journal of Institutional and Theoretical Economics, 2004, 142. 
and to the non-expert) which may make an accountability structure impracticable.

This leads to a wider challenge posed by GWG to research on globalization. As we saw, GWG's subject-matter is non-decisions and willing actions. This deprives us of the counterfactual test that underlies traditional approaches to power, making academic research in GWG an enterprise that calls for urgent new methodologies.

Indeed, arguing that "power" is A making B do something against B's will presumes that we know what B's will is, and can therefore ask: why is B not doing her will? How is A's power affecting B?

But, if B is doing something because it is her will; what, then, is our research question? If "expert power in action" is erasing through non-decisions all alternative options, how to know when we are actually observing an exercise of power? What are we to analyse? Where are the travaux préparatoires of non-decisions?

One could answer with scepticism. The notion of expertise as a form of power is mere "paranoid structuralism". ${ }^{11}$ We should make our theories fit our evidence, and not the other way around. If we cannot prove the existence of non-decisions, then perhaps we should drop the whole concept and focus in actual decisions, which can be proved and contested.

Yet, I doubt this is the way of going around such challenge. Scepticism is fallacious, because it turns a methodological difficulty into a substantive counter-argument. The methodological difficulty does not undermine the fact that expertise as a form of power is real. We can intuitively observe it everyday. We, ourselves, act like experts on any given day: we frame, we prioritize, and leave aside issues whose relevance we fully realize.

The point, then, is how to overcome the methodological difficulty. What is the right counterfactual to be used in order to prove that expert power is being deployed? Considering the all- important role of expertise in globalization, such a research agenda seems of relevance to make sense of power today.

91 "Paranoid structuralism teaches us that it is part of our modern social and individual psychological condition that we are playthings of forces whose existence and true relationships the 'normal' discourse of our world denies, thereby helping to reproduce the denied condition". Cfr. D. Kennedy, op. cit., note 65, at 1169. 
There is, thus, urgent need for new approaches to GWG. First, governance over water resources has to be better understood. Simply arguing that the WTO is selling our water to the rich will not cut it. And, when we start thinking about governance, we will start facing the daunting problem of expertise and accountability. And that may be, indeed, our departure point to start thinking about power over water resources. 